\title{
Central Amygdala GluA1 Facilitates Associative Learning of Opioid Reward
}

\author{
You-Qing Cai, ${ }^{1}$ Wei Wang, ${ }^{1}$ Yuan-Yuan Hou, ${ }^{1}$ Zhi Zhang, ${ }^{1}$ Jun Xie, ${ }^{2}$ and Zhizhong Z. Pan ${ }^{1}$ \\ ${ }^{1}$ Department of Anesthesiology and Pain Medicine, the University of Texas MD Anderson Cancer Center, Houston, Texas 77030, ${ }^{2}$ Gene Therapy Center, \\ University of Massachusetts Medical School, Worcester, Massachusetts 01605
}

GluA1 subunits of AMPA glutamate receptors are implicated in the synaptic plasticity induced by drugs of abuse for behaviors of drug addiction, but GluA1 roles in emotional learning and memories of drug reward in the development of drug addiction remain unclear. In this study of the central nucleus of the amygdala $(\mathrm{CeA})$, which is critical in emotional learning of drug reward, we investigated how adaptive changes in the expression of GluA1 subunits affected the learning process of opioid-induced context-reward association (associative learning) for the acquisition of reward-related behavior. In CeA neurons, we found that CeA GluA1 expression was significantly increased $2 \mathrm{~h}$ after conditioning treatment with morphine, but not $24 \mathrm{~h}$ after the conditioning when the behavior of conditioned place reference (CPP) was fully established in rats. Adenoviral overexpression of GluA1 subunits in CeA accelerated associative learning, as shown by reduced minimum time of morphine conditioning required for CPP acquisition and by facilitated CPP extinction through extinction training with no morphine involved. Adenoviral shRNA-mediated downregulation of CeA GluA1 produced opposite effects, inhibiting the processes of both CPP acquisition and CPP extinction. Adenoviral knockdown of CeA GluA2 subunits facilitated CPP acquisition, but did not alter CPP extinction. Whole-cell recording revealed enhanced electrophysiological properties of postsynaptic GluA2-lacking AMPA receptors in adenoviral GluA1-infected CeA neurons. These results suggest that increased GluA1 expression of CeA AMPA receptors facilitates the associative learning of context-drug reward, an important process in both development and relapse of drug-seeking behaviors in drug addiction.

\section{Introduction}

Drug addiction is a chronic, relapsing neuropsychiatric disorder characterized by compulsive behaviors of drug seeking and drug taking, driven by positive rewarding effects of drugs and negative emotional state during drug withdrawal (Hyman et al., 2006; Robbins et al., 2008; Koob and Volkow, 2010). The development of drug addiction engages active learning and memories that associate drug stimuli and related environmental cues with positive emotion of reward. The cellular mechanisms for learning and memory involve adaptive changes in glutamate synaptic strength particularly through altered subunit composition of AMPA receptors (Bowers et al., 2010). Thus, activity-driven synapses may be strengthened by membrane insertion of GluA2-lacking (i.e., GluA1/GluA1 or GluA1/GluR3) AMPA receptors, which have higher $\mathrm{Ca}^{2+}$ permeability and channel conductance than GluA2containing AMPA receptors (Isaac et al., 2007; Kauer and Malenka, 2007). GluA1, the predominant subunit of central

\section{Received April 10, 2012; revised Nov. 30, 2012; accepted Dec. 1, 2012.}

Author contributions: Y.-Q.C., W.W., Y.-Y.H., J.X., and Z.Z.P. designed research; Y.-Q.C., W.W., Y.-Y.H., and Z.Z. performed research; J.X. contributed unpublished reagents/analytic tools; Y.-Q.C., W.W., Y.-Y.H., Z.Z., and Z.Z.P. analyzed data; Y.-Q.C., W.W., and Z.Z.P. wrote the paper.

This work was supported by the National Institute on Drug Abuse Grants DA023069 and DA027541.

The authors declare no financial conflict of interest.

Correspondence should be addressed to Dr. Zhizhong Z. Pan, Department of Anesthesiology and Pain Medicine, The University of Texas M.D. Anderson Cancer Center, 1515 Holcombe Boulevard, Unit 110, Houston, TX 77030. E-mail:zzpan@mdanderson.org.

DOI:10.1523/JNEUROSCI.1749-12.2013

Copyright $\odot 2013$ the authors $\quad 0270-6474 / 13 / 331577-12 \$ 15.00 / 0$
AMPA receptors, has been shown to mediate an enhanced response to the rewarding effect of opioids in the ventral tegmental area (VTA) (Carlezon et al., 1997); however, direct activation of VTA AMPA receptors does not induce rewarding effect or behaviors of reward (Ikemoto et al., 2004). GluA1 also plays an important role in behaviors of cocaine seeking and reinstatement (Bachtell et al., 2008; Engblom et al., 2008). Nevertheless, it remains unknown how GluA1 may act to influence the contextual learning of rewarding effects of drugs through environmental cues-reward association, an important process in the development of drug addiction.

The central nucleus of the amygdala (CeA), as part of the brain's reward circuitry, is important in processing positive emotions and particularly, in the learning process of stimulus-reward association (Baxter and Murray, 2002; See et al., 2003). Many studies have demonstrated the important role of amygdala, including CeA and basolateral amygdala (BLA), in opioid reward. Activation of CeA NMDA receptors increases low-dose morphine-induced CPP (Rezayof et al., 2007) and the signaling pathway of NMDA receptor-extracellular signal-regulated kinase (ERK) in CeA is critical for expression of morphine CPP and for enhanced morphine CPP (incubation of morphine craving) after morphine withdrawal (Li et al., 2008; Li et al., 2011). Recently, He et al. found that blockade of protein kinase $\mathrm{M} \zeta$ (PKMzeta) in BLA, but not in CeA, inhibits morphine CPP (He et al., 2011). Additionally, ablation of neurokinin-1 receptor-expressing neurons in amygdala reduces morphine CPP (Gadd et al., 2003). 
In adult amygdala neurons, both GluA1 and GluA2 subunits are highly expressed and GluA2-containing (GluA1/GluA2) AMPA receptors are predominant (Zamanillo et al., 1999; Mead and Stephens, 2003a, b; Tye et al., 2011). While activitydependent synaptic long-term potentiation, a cellular model for learning and memory, can drive GluA1-containing AMPA receptors into synapses in hippocampal neurons (Hayashi et al., 2000), the function of CeA GluA1 subunits in the behavior of contextreward learning is largely unknown. In the current study in rats, we determined the behavioral effects of virally altered GluA1 and GluA2 expression in CeA neurons on the acquisition of morphine-induced CPP behavior, a widely used rodent model for measuring rewarding effects of drugs (Tzschentke, 2007).

\section{Materials and Methods}

Animals. All procedures involving the use of animals conformed to the guidelines set by the Institutional Animal Care and Use Committee of MD Anderson Cancer Center. Male Wistar rats (250-300 g) were housed in groups of three with food and water available ad libitum, and a $12 \mathrm{~h}$ light/dark cycle. All behavioral trainings and tests were performed between 8:00 A.M. and 18:00 pm.

Cannula implantation and microinjection. General methods for sitespecific microinjection were similar to those used in our previous studies (Zhu et al., 2007; Bie et al., 2009). Briefly, rats were anesthetized with sodium pentobarbital $(50 \mathrm{mg} / \mathrm{kg}$ i.p. $)$ and restrained in a stereotaxic apparatus. A 26-gauge, single guide cannula (Plastic One, Roanoke, VA) was inserted on each side of the brain, aiming at CeA (anteroposterior, $-2.3 \mathrm{~mm}$ from the bregma; lateral, $\pm 4.0 \mathrm{~mm}$; ventral, $-8.0 \mathrm{~mm}$ from dura) (Paxinos and Watson, 1986). The guide cannula was then cemented in place to the skull and capped after placement of a solid dummy cannula with the same length as the guide cannula. The implanted rats were housed individually and allowed to recover from the surgery for at least 1 week before experiments. Bilateral microinjection of a viral vector ( $1 \mu \mathrm{l}$ each side) into CeA was made through a 33 -gauge injector with an infusion pump at a rate of $0.1 \mu \mathrm{l} / \mathrm{min}$. All cannula placements for bilateral CeA injections were histologically verified afterward.

Adeno-associated viral (AAV) vectors. For construction of AAV-GluA1flip vector, the coding sequence of the rat GluA1 flip version (gene bank accession: M38060.1) (Sommer et al., 1990) was amplified by RT-PCR from rat brain mRNA with the primer pair: $5^{\prime}$-CCGAATTCTATGCCGTACAT CTTTGCC- ${ }^{\prime}$ and $5^{\prime}$-CCGTCGACTTACAATCCTGTGGCTCCCAAGG$3^{\prime}$. The PCR product was purified and inserted into pAAV-CMV backbone vector through EcoRI and SalI sites to obtain the pAAV-CMV-GluA1-flip vector. The vector was analyzed by PCR, restriction endonuclease analysis and sequencing to make sure there was no mutation in the GluAl coding sequence. The vector was further validated by expression of GluAl protein in $\mathrm{CHO}$ cells and then the validated vector was prepared for adeno virus packaging (Gao et al., 2002). For construction of AAV-GluA1-shRNA-GFP vector, four $21 \mathrm{nt}$ candidate sequences against rat GluA1 mRNA were selected with the BLOCK-iT RNAi Designer (Invitrogen) and then cloned into pAAVsc-si-EGFP shRNA expression vector with a loop sequence of TTCAAGAGA. The silence efficiency of these shRNA sequences was evaluated by co-transfection of each shRNA expression vector with pAAV-GluA1 vector into $\mathrm{CHO}$ cells. Transfected cells were harvested at $48 \mathrm{~h}$ posttransfection. AAV-GluA2-shRNA vectors were similarly constructed, validated and packaged. GluA1 and GluA2 expression levels of each sample were evaluated by Western blot. The most effective vector was selected and marked as AAV-GluA1-shRNA containing the shRNA sequence 5'-GGAA TCCGAAAGATTGGTTAC-3' (M38060.1, 1123-1143), and AAV-GluA2shRNA with the sequence 5'-GGAGCACACACAGCGACAATT-3' (NM017261, 1289-1309). Animals were injected with $1 \mu \mathrm{l}\left(\sim 5 \times 10^{-9}\right.$ $\mathrm{GC} / \mu \mathrm{l}) \mathrm{AAV}-\mathrm{GluA} 1$ virus, or $1 \mu \mathrm{l}\left(\sim 2 \times 10^{9} \mathrm{GC} / \mu \mathrm{l}\right) \mathrm{AAV}-\mathrm{GluA} 1$-shRNAGFP or $1 \mu \mathrm{l}\left(1.5 \times 10^{-9} \mathrm{GC} / \mu \mathrm{l}\right) \mathrm{AAV}-\mathrm{GluA} 2$-shRNA-GFP virus into CeA on each side of the brain. All behavioral experiments were performed $10 \mathrm{~d}$ after the virus injection.

CPP and extinction training. The general CPP procedure has been described in our previous studies (Zhu et al., 2007; Bie et al., 2009). With a standard 3-chamber CPP apparatus (MED Associates, St. Albans, VT), each conditioning session, conducted around 6 P.M., consisted of one cycle of saline (s.c.) conditioning on one day and morphine (s.c.) conditioning on the following day, and CPP behavior was measured at 9 A.M. in posttests after 1, 2, 4 or 5 sessions of conditioning treatment (45 min each) and $1 \mathrm{~d}$ post-conditioning. A saline injection (s.c.) without conditioning was made before each CPP test. In this study, control rats displayed baseline preference for one chamber (equipment bias) and morphine conditioning was mostly paired with the non-preferred chamber. CPP was also consistently induced by pairing with the preferred chamber (Zhu et al., 2007). CPP behavior was defined by statistical difference in times spent in the morphine-paired chamber before conditioning treatment in pretest and in the posttest in the same rats. CPP data were presented as actual times a rat spent in the morphine-paired chamber in pretests and posttests. CPP extinction was achieved by once daily conditioning with saline (s.c.) only and was measured by a CPP test on every other day to minimize its inference with extinction training. After the behavioral experiments, brain slices (600 $\mu \mathrm{M}$ thick) containing the CeA were cut on a vibratome (Leica Microsystems) and CeA tissues were punched out by a pipette tip with an inner diameter of $1.5 \mathrm{~mm}$ for biochemical analyses.

Western blot analysis. $\mathrm{CHO}$ cells were transfected with plasmids (pAAV-GluA1, pAAV-GluA1-shRNA, pAAV-GluA2-shRNA and control vectors) and harvested after $48 \mathrm{~h}$. The cells were lysed in $200 \mu \mathrm{l}$ RIPA buffer and supplemented with Complete Protease Inhibitor tablets (Roche). Samples were mixed with $2 \times$ SDS loading buffer and denatured at $70^{\circ} \mathrm{C}$ for $15 \mathrm{~min}$. For total protein preparation, CeA tissues were homogenized in $150 \mu$ l RIPA buffer with fresh protease inhibitor, the lysate was centrifuged and the supernatant was kept as total protein samples. For crude synaptosome preparation (Bie et al., 2009), CeA tissues were gently homogenized in sucrose buffer and centrifuged at $1000 \times g$. The supernatant was centrifuged at $10000 \times g$ for $20 \mathrm{~min}$ and the synaptosomal pellet was resuspended in $80 \mu \mathrm{l}$ RIPA lysis buffer. Protein concentration of each sample was determined by the DC protein assay from Bio-Rad. Equal amounts of protein $(25 \mu \mathrm{g}$ for total protein, $7.5 \mu \mathrm{g}$ for crude synaptosome) were loaded per lane and separated on an $8 \%$ SDSPAGE gel. The PVDF membranes with transferred protein were incubated overnight at $4^{\circ} \mathrm{C}$ with the primary antibodies against GluAl (1: 1,000, Millipore, catalog no. 05-855R), phospho-GluA1-Ser845 (1:3,000, Millipore, catalog no. 04-1073), GluA2 (1:1,000, Santa Cruz Biotechnology, catalog no. sc-7610), and $\beta$-actin (1:1,000, Santa Cruz Biotechnology, catalog no. sc-81178). After washes, the blots were incubated with horseradish peroxidase-conjugated secondary antibodies (1:10,000, Jackson ImmunoResearch) for $1 \mathrm{~h}$. The blots were developed with ECL plus reagent (GE Healthcare). The densitometric quantification of immunoreactive bands was performed with the AlphaView software (Alpha Innotech).

Whole-cell recording. General recording methods have been reported before (Zhang and Pan, 2010; Zhang et al., 2011). Coronal slices (240 $\mu \mathrm{m})$ containing the amygdala were cut from the brain of virus-injected rats and maintained in a preheated $\left(35^{\circ} \mathrm{C}\right)$ physiological solution containing (in mM): $\mathrm{NaCl}, 126 ; \mathrm{KCl}, 2.5 ; \mathrm{NaH}_{2} \mathrm{PO}_{4}, 1.2 ; \mathrm{MgCl}_{2}, 1.2 ; \mathrm{CaCl}_{2}$, 2.4; glucose, $11 ; \mathrm{NaHCO}_{3}, 25$, saturated with $95 \% \mathrm{O}_{2}$ and $5 \% \mathrm{CO}_{2}, \mathrm{pH}$ 7.2-7.4. Virus-transfected neurons were identified by GFP signals in CeA slices from rats after single-side CeA injection of mixed viruses (AAVGluA1+AAV-GFP, 3:1) for GluA1-overexpressing cells or AAV-GluA1shRNA-GFP for cells with GluA1 knockdown. Due to the limited packaging capacity of AAV that prevents expression of both GluA1 and GFP in one vector, the GFP-expressing cells near the injection track in CeA from rats injected with the mixed viruses were approximately considered as GluA1-overexpressing cells, and control cells were those in CeA of the other uninjected side in the slice. Visualized whole-cell voltage-clamp recordings were obtained from GFP-labeled, infected neurons and GFP-negative control neurons in $\mathrm{CeA}$ with a glass pipette filled with a solution containing (in $\mathrm{mM}$ ): cesium methansulphonic acid, 120; HEPES, 20; EGTA, 0.4; $\mathrm{MgCl}_{2}, 2.0$; TEA-Cl, 5; Mg-ATP, 2.5; $\mathrm{Na}_{2}$ GTP, 0.25; QX-314-Cl, 1; pH 7.2-7.4, 280-290 mOsm. For rectification analysis, spermine $(100 \mu \mathrm{M})$ was added to the pipette solution. Electrical stimuli of constant current $(0.25 \mathrm{~ms}, 0.2-0.5 \mathrm{~mA})$ were used to 
A
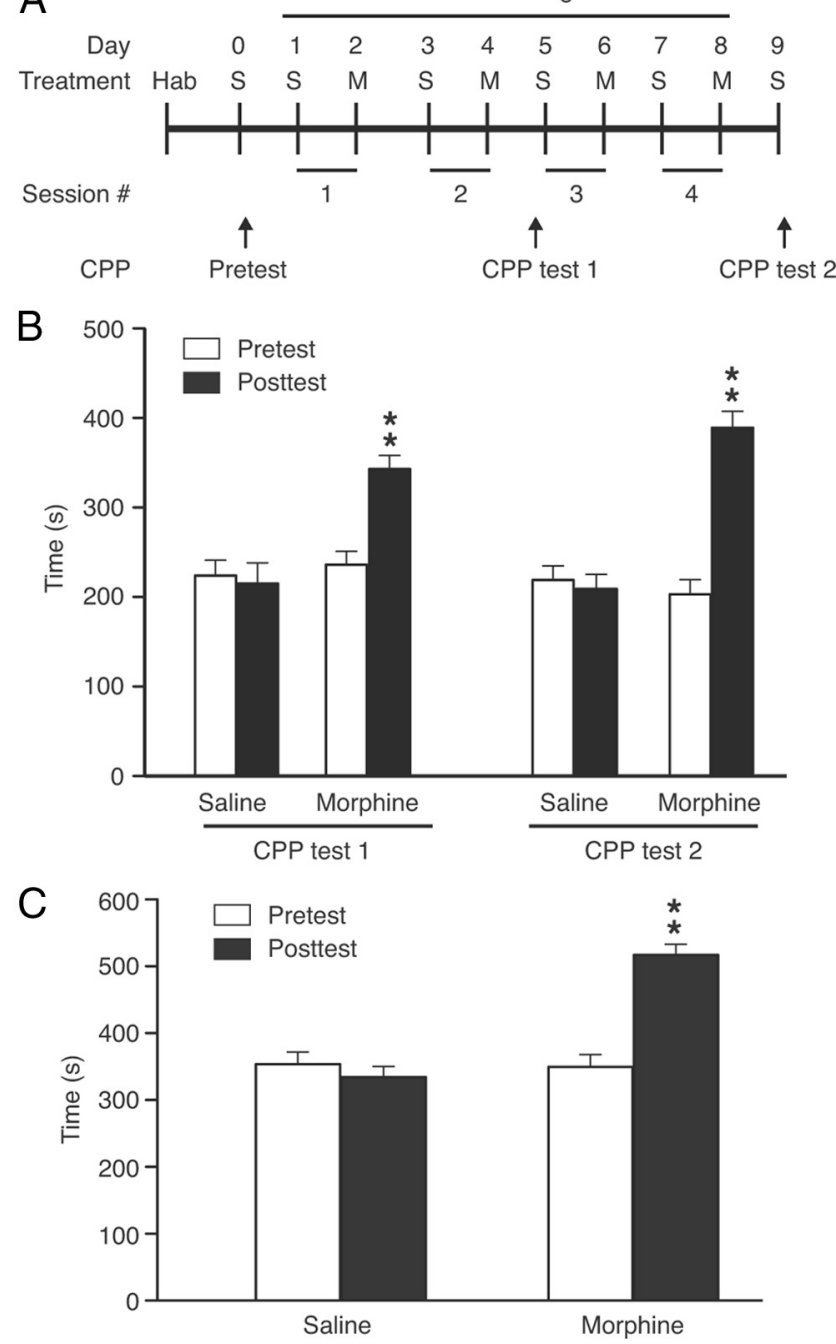

D 2 sessions
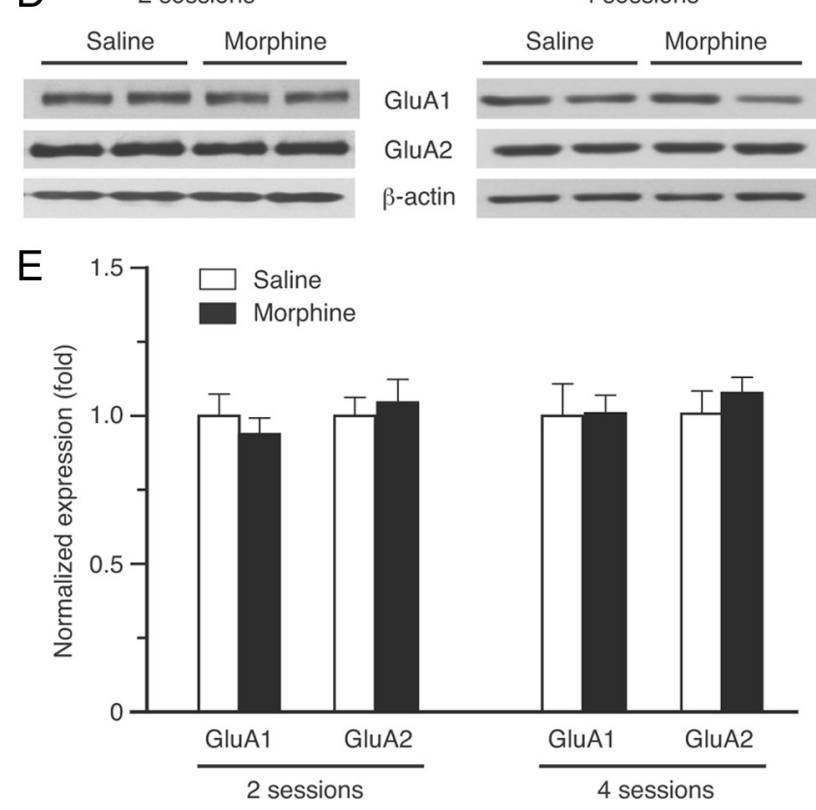

Figure 1. Morphine conditioning induces behavior of conditioned place preference (CPP) without altering protein expression of AMPA receptor GluA1 and GluA2 subunits in the central nucleus of the amygdala (CeA). $\boldsymbol{A}$, Timeline of experimental protocol for morphine conditioning and CPP tests. Hab, habituation; $S$, saline; M, morphine. $B$, CPP in rats induced by conditioning evoke postsynaptic currents with a bipolar stimulating electrode placed in the basolateral amygdala (BLA). All recordings were performed in the presence of picrotoxin $(50 \mu \mathrm{M})$. To calculate the AMPA/NMDA ratio, the AMPA receptor-mediated excitatory postsynaptic current (EPSC) was determined by the averaged amplitude of ten EPSCs at $+40 \mathrm{mV}$ in the presence of D-AP5 $(50 \mu \mathrm{M})$ and the NMDA receptor-mediated EPSC was obtained by subtracting the AMPA EPSC from the total EPSC. The rectification index (RI) of AMPA receptors was obtained by the equation: $\mathrm{RI}=\left[\mathrm{EPSC}_{-70} /\left(70-E_{\mathrm{rev}}\right)\right] /\left[\mathrm{EPSC}_{+40} /\left(40-E_{\text {rev }}\right)\right]\left(\mathrm{EPSC}_{-70}\right.$ and EPSC $_{+40}$, EPSCs recorded at a holding potential of -70 and $+40 \mathrm{mV}$, respectively; $E_{\text {rev }}$, reversal potential calculated from the $I-V$ relationship) (Balland et al., 2006; Conrad et al., 2008). All drugs were applied through the bath solution unless stated otherwise.

Immunohistochemistry. AAV-injected animals were deeply anesthetized with sodium pentobarbital (60 mg/kg i.p.) and perfused transcardially with heparinized saline followed by $4 \%$ paraformaldehyde in $0.1 \mathrm{~m}$ phosphate buffer. The brain was extracted and post-fixed overnight at $4^{\circ} \mathrm{C}$, and cryoprotected in $30 \%$ sucrose in $0.1 \mathrm{~m}$ phosphate buffer. Consecutive $30 \mu \mathrm{m}$ coronal brain sections were prepared and stored in PBS (containing $0.1 \%$ sodium azide). For GFP expression, sections were mounted on slides, dried and coverslipped with ProLong Gold antifade reagent for DAPI staining (Invitrogen). For GluA1 staining, sections were blocked with 5\% normal donkey serum (NDS) in PBS containing $0.3 \%$ Triton X-100 and incubated overnight with anti-GluA1 antibody (1:500, Millipore, catalog no. 05-855R). Sections were then rinsed and incubated with the Alexa Fluor-conjugated secondary antibodies: Alexa Fluor 568 goat anti-rabbit IgG (1:500, Invitrogen). The stained sections were examined with a Nikon E600 fluorescence microscope (Nikon Instech).

Novel object recognition test. This test, consisting of three phases of habituation, acquisition trial, and retention trial, was performed to assess learning of novel objects and recognition memory according to the procedures described in a previous report (Bevins and Besheer, 2006). Seven days after viral injection, a rat was habituated to an open-field arena for 20 min on three consecutive days. In an acquisition trial, the rat was given 3 min to explore the arena with two identical objects: two cans of Coca Cola or two plastic water bottles of similar sizes. The exploration time the rat spent on each object was recorded. In a retention trial $4 \mathrm{~h}$ after the acquisition trial, the animal was returned and allowed to explore the arena with one can of Coca Cola and one water bottle for $3 \mathrm{~min}$. The exploration time on the familiar object (presented in the acquisition trial) and on the novel object (not presented in the acquisition trial) was recorded. All objects and the test box were cleaned with $70 \%$ ethanol between rats to remove odor cues. Novel preference in percentage was calculated by the time exploring on the novel object divided by total exploration time on both novel and familiar objects.

Data analysis and materials. Numeral data of CPP and EPSCs before and after a treatment were statistically compared and analyzed with Student's $t$ tests or one-way ANOVA. For behavioral data of CPP and extinction time courses involving multiple treatments or CPP tests, two-way ANOVA for repeated measures with post hoc analysis of the Bonferroni method was used to determine statistical significance in group treatment and between-group interactions at each time point. Data were expressed as mean \pm SEM, and a $p$ value $<0.05$ was considered statistically significant. All statistical analyses were performed with the Prism software version 5.04 (GraphPad Software). Morphine hydrochloride was kindly supplied by the National Institute on Drug Abuse. All other drugs were purchased from Tocris Bioscience or from Sigma-Aldrich.

$\leftarrow$

with morphine ( $10 \mathrm{mg} / \mathrm{kg}$, s.c.) paring with the non-preferred chamber after 2 (CPP test 1$)$ or 4 (CPP test 2) conditioning sessions ( $n=6$ rats each group). C, CPP induced by morphine (10 $\mathrm{mg} / \mathrm{kg}$, s.c.) paring with the preferred chamber after 4 conditioning sessions ( $n=6$ rats/ group). $\boldsymbol{D}, \boldsymbol{E}$, Western blotting $(\boldsymbol{D})$ and summarized results $(\boldsymbol{E})$ of GluA1 and GluA2 protein levels in synaptosomal preparations of CeA from rats ( $n=5 /$ group) conditioned with saline or morphine with established CPP after 2 or 4 conditioning sessions. GluR protein levels were normalized to that of $\beta$-actin. ${ }^{* *} p<0.01$. 
A
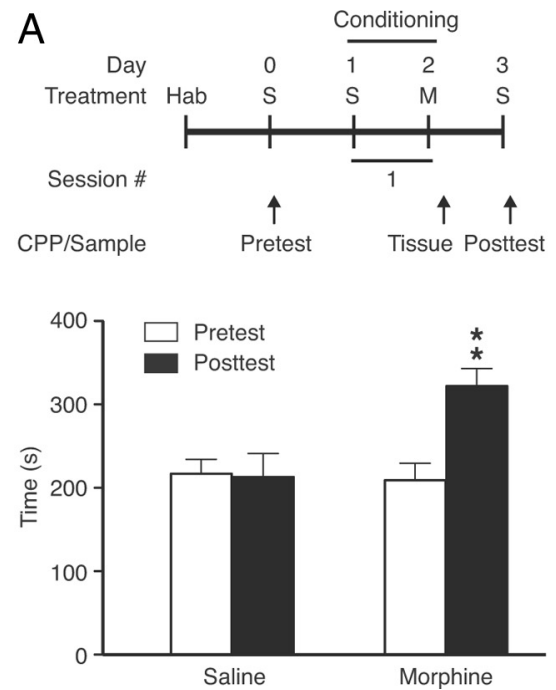

B

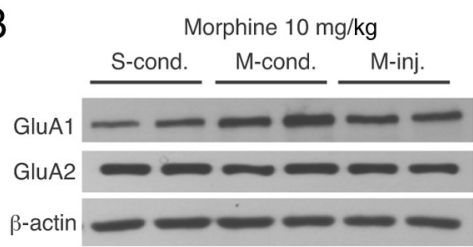

C

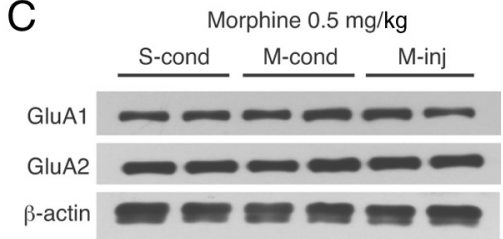

Figure 2. Morphine conditioning transiently increases the protein level of synaptosomal GluA1 in CeA. $A$, Timeline of experimental protocol (upper) and CPP induced by one conditioning session with morphine (10 mg/kg, s.c., lower) ( $n=6$ rats/group). $B, C$, Western blot data of CeA synaptosomal GluA1 and GluA2 proteins from rats conditioned with one session of saline ( $S$-cond.) or morphine (M-cond., $10 \mathrm{mg} / \mathrm{kg}$ ) (B) or a sub-threshold morphine dose at $0.5 \mathrm{mg} / \mathrm{kg}(\boldsymbol{C})$, or injected in home cage without conditioning with the same two doses of morphine (M-inj., $\boldsymbol{B}, \boldsymbol{C})$. CeA tissues were collected $2 \mathrm{~h}$ after morphine conditioning as shown in $A$ ( $n=6 /$ group). ${ }^{*} p<0.05,{ }^{* *} p<0.01$.

\section{Results}

\section{GluA1 upregulation during proposed learning consolidation} of morphine reward

We first examined the expression level of GluA1 in CeA from rats with morphine-induced CPP. Conditioning with morphine pairing with the non-preferred chamber at a dose of $10 \mathrm{mg} / \mathrm{kg}$ (s.c.) induced significant CPP behavior after 2 conditioning sessions $\left(t_{(5)}=6.962, p<0.01\right.$, Fig. $\left.1 A, B\right)$. Continued conditioning with four such sessions produced CPP with no further increase in CPP magnitude $\left(t_{(5)}=6.080, p<0.01\right)$. Conditioning with morphine paring with the preferred chamber also consistently induced CPP $\left(t_{(5)}=4.487, p<0.01\right.$, Fig. $\left.1 C\right)$. In CeA tissues taken from rats after two or four sessions following posttest 1 or posttest 2 (Fig. $1 A$ ), we found no significant change in the levels of synaptosomal GluA1 and GluA2 proteins between control rats and rats with morphine-induced CPP (Fig. $1 D, E$ ). No change was found either in total protein levels of CeA GluA1 and GluA2 (data not shown).

We therefore predicted that CeA GluAl might be important for the learning and consolidation process of environmental cues-reward association in CPP behavior, which occurs several minutes to several hours after conditioning training (McGaugh, 2000). To examine this, rats were then conditioned by a single conditioning session with morphine $(10 \mathrm{mg} / \mathrm{kg}$, s.c. $)$, which also induced significant $\mathrm{CPP}\left(t_{(5)}=6.513, p<0.01\right.$, Fig. $\left.2 A\right)$. In CeA tissues harvested $2 \mathrm{~h}$ after morphine conditioning, we found a significant increase (about 34\%) in synaptosomal GluA1 when compared to saline-conditioned control rats $\left(t_{(8)}=2.572, p<\right.$ 0.05 , Fig. $2 B$ ). Morphine injection $(10 \mathrm{mg} / \mathrm{kg}$, s.c.) in home cage without conditioning (chamber pairing) induced a small increase in the GluA1 protein expression, but it did not reach statistical significance $\left(t_{(8)}=1.671, p=0.1332\right.$, Fig. $\left.2 B\right)$. In contrast, the GluA2 level remained unchanged across the three rat groups. In addition, the level of CeA synaptosomal GluA1 expression remained unchanged in single session-conditioned rats with a low dose of morphine ( $0.5 \mathrm{mg} / \mathrm{kg}$, s.c., Fig. $2 C)$, which failed to induce CPP (see results of Fig. $4 \mathrm{~A}$ below). Thus, it appears likely that CeA GluA1 plays a role in the learning/consolidation process of context-reward association for morphine-induced CPP behavior.

\section{GluA1 overexpression facilitates associative learning of} morphine reward

To determine this GluA1 role, we overexpressed GluA1 in CeA by using an adeno-associated viral (AAV) vector. Lysate of $\mathrm{CHO}$ cells transiently transfected by a constructed vector (pAAVGluA1) showed a strong immunoreactive band of GluAl (Fig. $3 A)$. After bilateral microinjection of the vector packaged in AAV2 virus (AAV-GluA1, $1 \mu \mathrm{l}, 5 \times 10^{9} \mathrm{GC}$ ) into CeA, we found a 1.5 fold increase in GluA1 expression in CeA tissues collected 7 and $14 \mathrm{~d}$ post-injection when compared to CeA tissues of control rats similarly injected with AAV-GFP virus $\left(7 \mathrm{~d}: t_{(10)}=5.056, p<\right.$ $0.01 ; 14$ d: $t_{(10)}=3.741, p<0.01$, Fig. 3B,C). Phosphorylated GluA1-Ser845 subunits, an activated form required for membrane trafficking of AMPA receptors (Choi et al., 2011), were also increased in CeA of AAV-GluA1-injected rats. The AAV-GluA1 virus did not alter the expression of GluA2 subunits in CeA (Fig. $3 B, C$ ), indicating a selective overexpression of GluA1 by the virus. Supporting the GluA1 overexpression induced by CeA microinjection of the AAV-GluAl viruses (Fig. 3D a-c), CeA neurons showed clearly stronger signals of immunoreactive GluA1 in the AAV-GluA1-injected side of CeA than those on the uninjected side (Fig. 3Dd-f).

We then used these rats with viral overexpression of CeA GluA1 to examine the CPP acquisition phase (from pretest to the first significant $\mathrm{CPP}$ ) during which CeA-involved learning and consolidation of context-reward association (associative learning) is proposed to occur for the CPP behavior. Conditioned with morphine at $0.5 \mathrm{mg} / \mathrm{kg}$ (s.c.), naive rats required a minimum of three conditioning sessions to acquire significant $\mathrm{CPP}$, with more conditioning sessions inducing similar $\mathrm{CPP}$ in magnitude (Fig. $4 A$, two-way ANOVA: conditioning, $F_{(6,84)}=3.81, p=0.002$; morphine, $\left.F_{(1,14)}=6.47, p=0.023\right)$. Rats injected with AAVGFP in the CeA displayed a similar time course of CPP acquisition to that of naive rats, requiring at least 3 conditioning sessions for CPP induction (Fig. 4B). In contrast, in rats with CeA injection of AAV-GluA1, a singe conditioning session with the same morphine dose $(0.5 \mathrm{mg} / \mathrm{kg}$, s.c.) was sufficient to induce significant CPP (Fig. 4B). Moreover, the CPP magnitude in these rats 

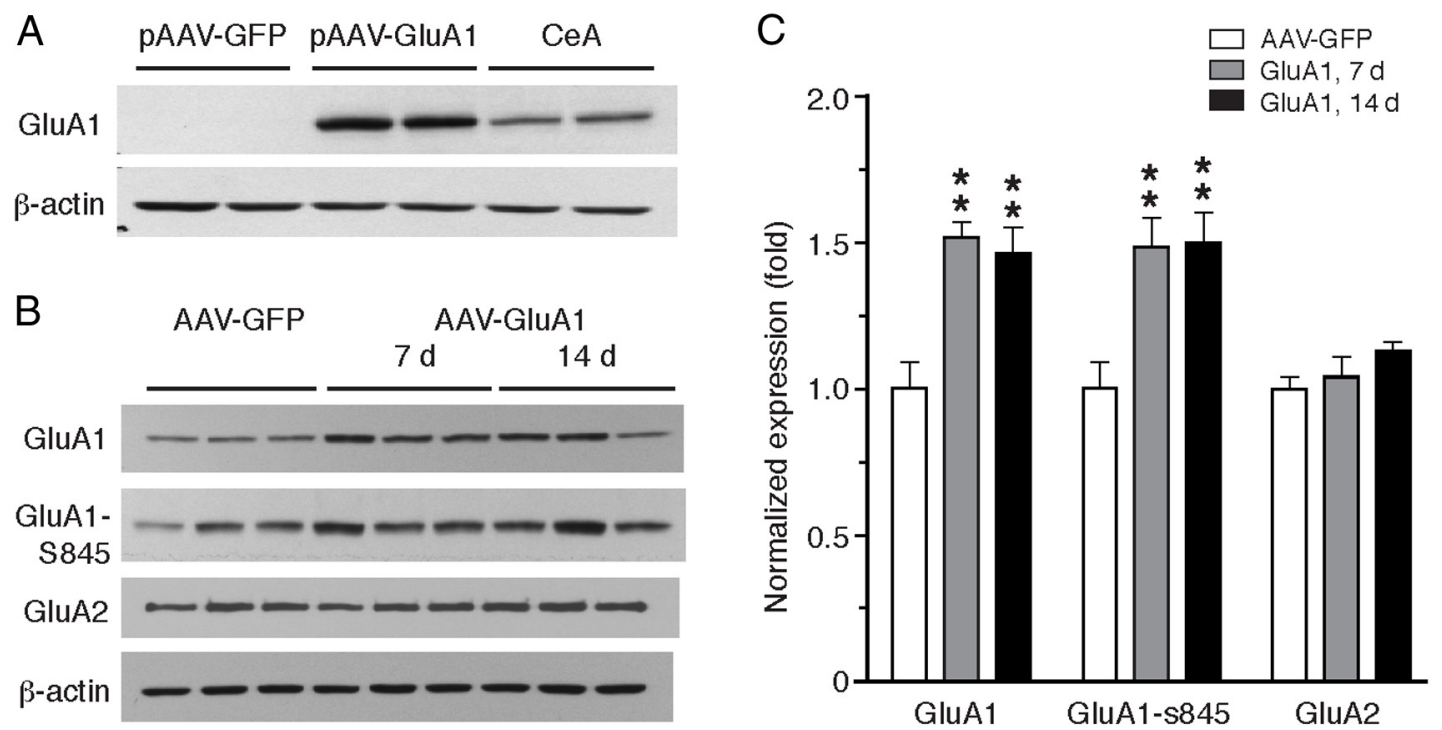

$\mathrm{D}$
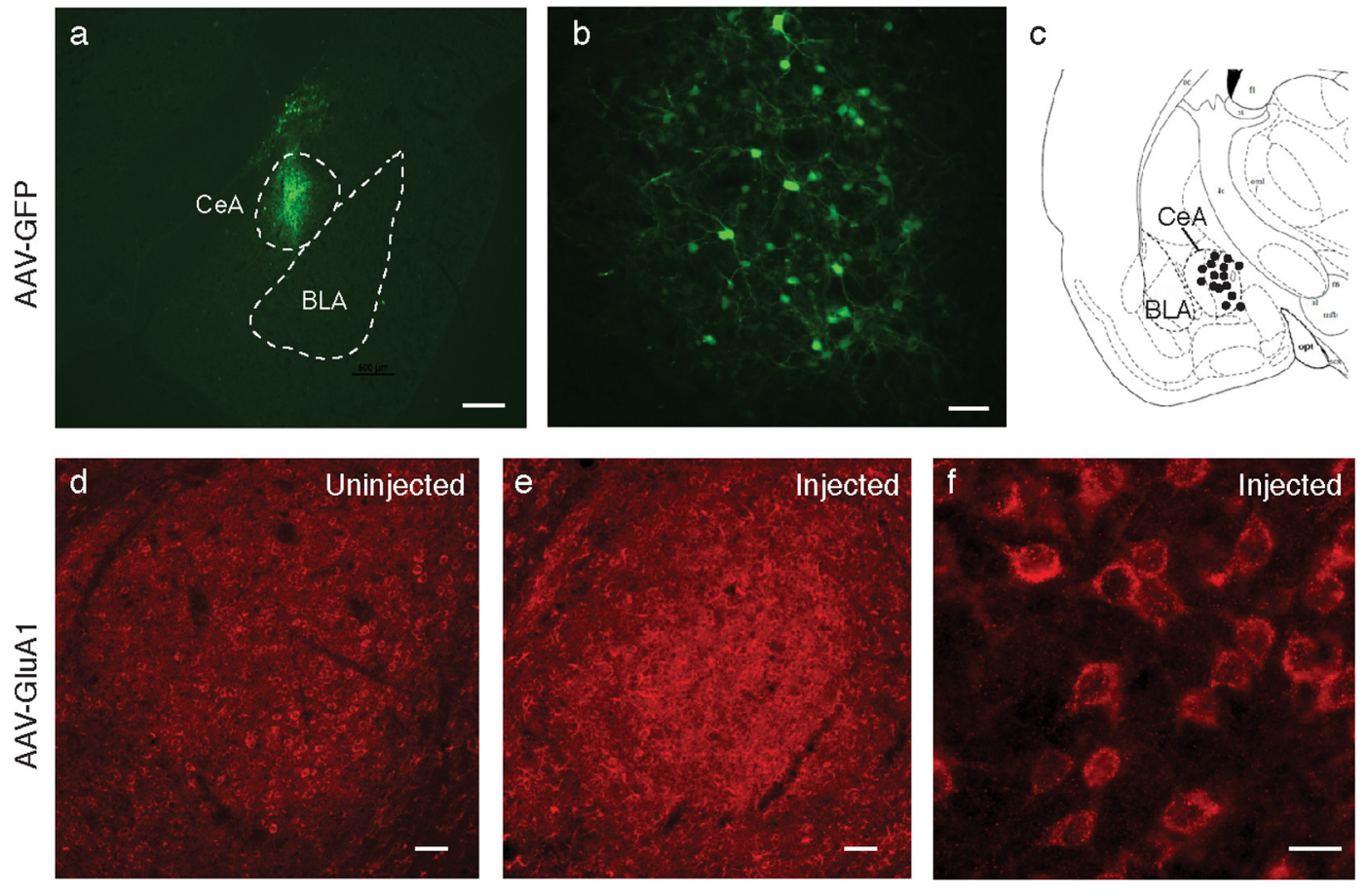

Figure 3. Adeno-associated virus (AAV) vector-mediated overexpression of GluA1 subunits in CeA. $A$, Validation of AAV plasmid carrying the cDNA encoding rat GluA1(flip) in cultured CHO cells. Control cells were transfected with AAV-GFP plasmid and samples from CeA tissues were shown as positive control. $\boldsymbol{B}, \boldsymbol{C}$, Western blot data $(\boldsymbol{B})$ and summarized results $(\boldsymbol{C})$ of GluA1, phosphorylated GluA1 at $\$ 845$ and GluA2 proteins in CeA tissues collected from rats $(n=6 /$ group $) 7$ or $14 \mathrm{~d}$ after bilateral intra-CeA infusion of $1 \mu$ IAAV-GluA1 virus or AAV-GFP virus. $D$, Representative micrographs of immunostaining and illustration after CeA microinjection, showing AAV-mediated eGFP expression within the defined boundary of (eA in low magnification $(\boldsymbol{a}$, scale bar $=500 \mu \mathrm{m})$ and high magnification ( $\boldsymbol{b}$, scale bar $=50 \mu \mathrm{m})$, a diagram depicting successful injection sites (black dots) within the CeA (c), and CeA GluA1 expression from a rat in an uninjected side ( $\boldsymbol{d}$, scale bar $=50 \mu \mathrm{M})$ and in the other side injected with AAV-GluA1 in low $(\boldsymbol{e}$, scale bar $=50 \mu \mathrm{M})$ and high magnification $(\boldsymbol{f}$, scale bar $=20 \mu \mathrm{m})$. CeA preparations were prepared at post-injection day $10 .{ }^{* *} p<0.01$.

further increased with each additional conditioning session until after four sessions, and was significantly larger after each session and at the post-conditioning test than those in AAV-GFPinjected rats (Fig. $4 B$, two-way ANOVA: conditioning, $F_{(6,78)}=$ 23.57, $p=0.0001$; GluA1, $\left.F_{(1,13)}=13.06, p=0.003\right)$. Saline conditioning of naive or AAV-GluA1-injected rats did not induce $\mathrm{CPP}$ after these conditioning sessions. These results support the notion that the enhanced effect of morphine in CPP acquisition of morphine reward is mediated, at least partially, by increased CeA GluA1 function that facilitates the learning and consolidation of morphine reward in CPP behavior.
To further determine this facilitating effect of GluAl on the associative learning, we examined the behavior of CPP extinction induced by extinction training, a new form of associative learning that is required to reduce CPP and drug-seeking behavior (Sutton et al., 2003). Conditioning with a higher dose of morphine (3 $\mathrm{mg} / \mathrm{kg}$ ) induced CPP after a single session in both groups of AAV-GFP-injected control rats and AAV-GluA1-injected rats, but stronger CPP was induced in the AAV-GluA1 group after each conditioning session than controls during CPP acquisition (Fig. 4C). During CPP extinction induced by daily sessions of conditioning with saline only, a single session of extinction train- 
ing significantly reduced the CPP in the AAV-GluA1 group so that the remaining CPP was no longer different from that in the AAV-GFP group. After that, the CPP in both groups extinguished at a similar rate following additional training sessions, with the same number of extinction sessions required to reach complete extinction in both groups (Fig. 4C, two-way ANOVA: conditioning, $F_{(5,70)}=18.47$, $p=0.0001$; GluA1, $F_{(1,14)}=10.28, p=$ $0.006)$. To exclude the possibility that CPP of a higher magnitude would naturally extinguish faster, we did similar extinction experiments in two groups of naive rats with statistically different magnitudes of CPP behaviors induced by two different doses of morphine $(3 \mathrm{mg} / \mathrm{kg}$ and $10 \mathrm{mg} / \mathrm{kg}$ ). As shown in Figure $4 D$, whereas the CPP of lower magnitude was completed extinguished after 5 sessions, the CPP of higher magnitude extinguished much slower, with significant CPP behavior remaining after 9 training sessions (two-way ANOVA: extinction training, $\mathrm{F}_{(6,84)}=38.02$, $p=0.0001$; morphine dose, $\left.F_{(1,14)}=7.31, p=0.017\right)$. Thus, as the extinction training engages a separate form of associative learning without involvement of a morphine effect, these findings further support the notion that upregulation of CeA GluA1 function facilitates associative learning in CPP behavior.

\section{GluA1 downregulation inhibits associative learning of morphine reward}

To further validate the learning-facilitating effect of CeA GluA1, we used an AAVGluA1-shRNA vector to downregulate the expression of GluA1 in CeA. Western blotting analysis showed that, $10 \mathrm{~d}$ after bilateral infusion of $1 \mu \mathrm{l}$ AAV-GluA1-shRNA-GFP vector into CeA, the level of synaptosomal GluA1 protein was decreased by about $36 \%$ in CeA tissues when compared to that from rats injected with AAV-scrambled shRNA vector $\left(t_{(6)}=5.552, p<0.01\right.$, Fig. $\left.5 A\right)$. Consistent with reports of several previous studies (Zamanillo et al., 1999; Mead and Stephens, 2003a, b), the expression level of synaptosomal GluA2 protein also was decreased to a less extent in GluA1-shRNA-injected rats for unknown mechanisms $\left(t_{(6)}=3.727, p<0.01\right.$, Fig. 5A). This GluA1shRNA-mediated GluA1 downregulation was confirmed by immunohistochemical staining of GFP-positive CeA neurons for GluA1 immunoreactivity (Fig. 5B).

In AAV-scrambled shRNA-injected control rats, one conditioning session with morphine at $3 \mathrm{mg} / \mathrm{kg}$ (s.c.) induced CPP, with more morphine-conditioning sessions producing slightly stronger CPP (Fig. 5C), similar to the CPP acquisition by the same morphine dose in AAV-GFP-injected control rats (Fig. 4C). However, in rats with CeA injection of AAV-GluA1-shRNA, similar morphine conditioning failed to induce CPP even after two
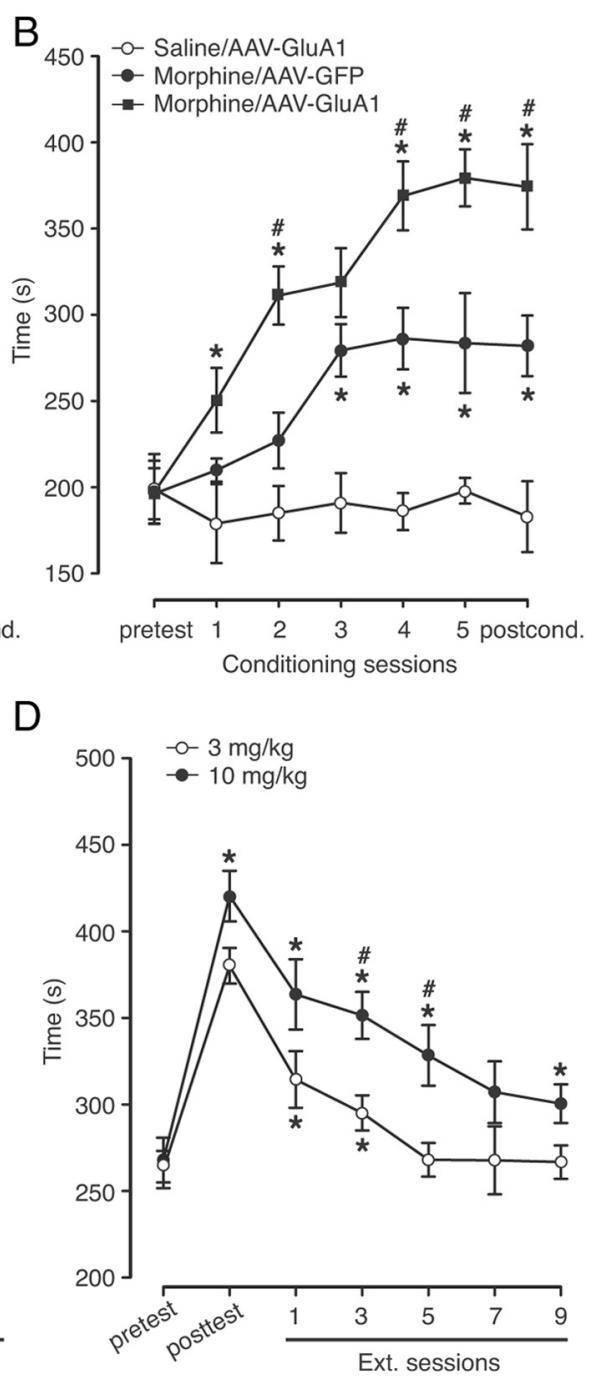

Figure 4. Overexpression of CeA GluA1 subunits facilitates associative learning of morphine reward. $A$, Behaviors of CPP induced by multiple conditioning sessions with saline or a low dose of morphine ( $0.5 \mathrm{mg} / \mathrm{kg}$, s.c.) ( $n=6$ rats $/$ group). (PP tests were conducted after each number of sessions and after the completion of all conditioning sessions (postcond., postconditioning)

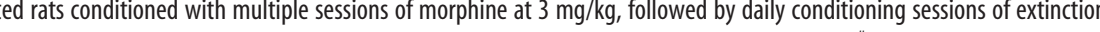
AAV-GFP group); ${ }^{* *} p<0.01$; n.S., not significant. D. (PP behaviors in normal rats ( $n=8 /$ group) induced by conditioning with morphine at $3 \mathrm{mg} / \mathrm{kg}$ and $10 \mathrm{mg} / \mathrm{kg}$, followed by daily sessions of extinction training. ${ }^{*} p<0.05$ (compared to the pretest in the same group); " $p<0.05$ (compared to the $3 \mathrm{mg} / \mathrm{kg}$ group).

sessions and at least three sessions were required to induce significant CPP, which was significantly smaller in magnitude than that in the control group (Fig. 5C). Of note is that the GluA1-shRNAinjected rats was able to acquire CPP that was comparable in magnitude to that of control rats after five conditioning sessions, making it unlikely that the delay in CPP acquisition was due to a reduced pharmacological effect of morphine. Consistent evidence was shown in analysis of CPP extinction. The CPP in scrambled shRNA-injected control rats diminished to almost complete extinction after five sessions of extinction training, whereas the CPP in GluA1-shRNA-injected rats largely persisted with most CPP remaining after such 5 training sessions (Fig. $5 C$, two-way ANOVA: conditioning, $F_{(5,90)}=20.43, p<0.001$; GluA1-shRNA, $F_{(1,18)}=8.38, p=0.0096$; extinction training, $F_{(3,54)}=17.25, p<0.0001$; extinction/GluA1-shRNA, $F_{(1,18)}=$ 
A

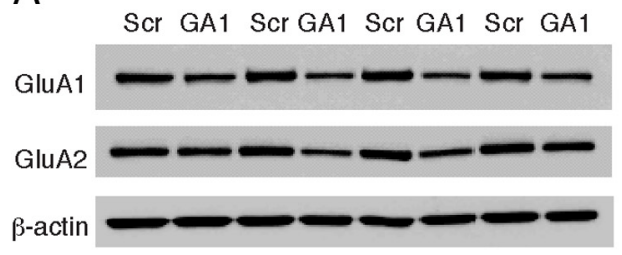

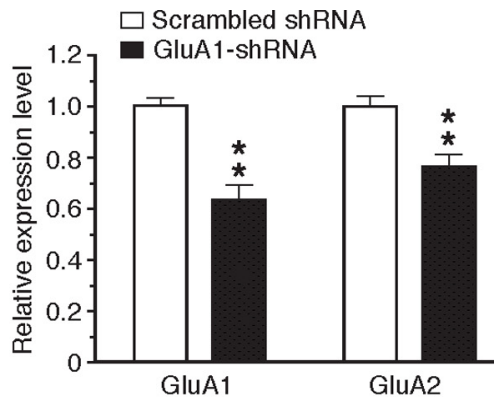

B
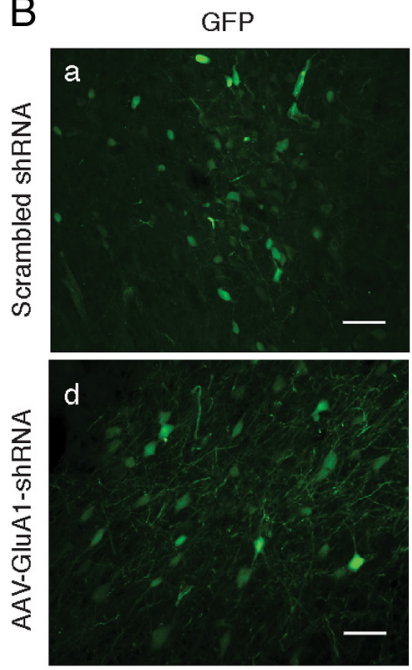

C

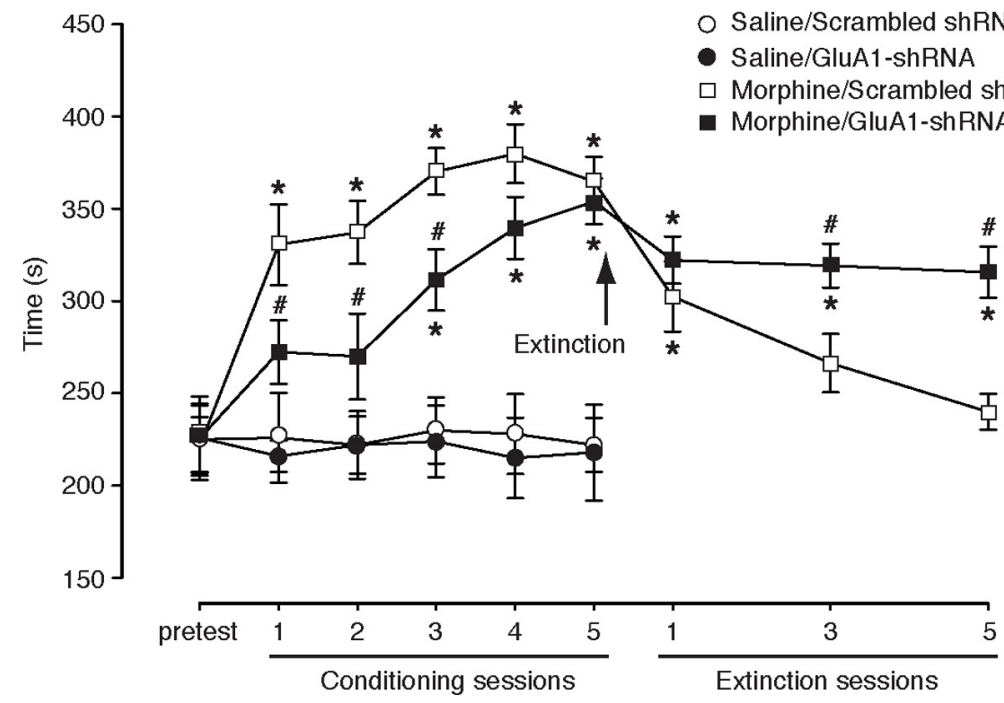

Figure 5. AAV-GluA1-shRNA-mediated downregulation of CeA GluA1 subunits inhibits associative learning of morphine reward. $A$, Western blotting analysis of CeA synaptosomal GluA1 (GA1) and GluA2 proteins in rats ( $n=6 /$ group) with bilateral CeA injection of AAV-GluA1-shRNA or AAV-scrambled (Scr) shRNA. CeA tissues were collected at post-injection day $10 .{ }^{* *} p<0.01 . \boldsymbol{B}$, Representative micrographs of GluA1 immunoreactivity and GFP expression in CeA neurons from a rat after CeA injection of AAV-scrambled shRNA $(\boldsymbol{a}-\boldsymbol{c})$ or AAV-GluA1-shRNA $(\boldsymbol{d}-\boldsymbol{f})$. Scale bars, $50 \mu \mathrm{m}$. C, CPP behaviors in rats with bilateral CeA injection of AAV-scrambled shRNA or AAV-GluA1-shRNA after multiple conditioning sessions with saline ( $n=6$ rats/group) or morphine (3 $\mathrm{mg} / \mathrm{kg}, n=10 \mathrm{rats} / \mathrm{group}$ ), followed by daily conditioning sessions of extinction training. ${ }^{*} p<0.05$ (compared to the pretest in the same group); $\#<<0.05$ (compared to the morphine/scrambled shRNA group).

7.16, $p=0.015)$. These results indicate that downregulation of CeA GluA1, together with some downregulation of GluA2, inhibits associative learning in a drug-free context of reward-related behavior, providing further support for the facilitating effect of CeA GluA1 on associative learning of opioid reward.
GluA1-overpressing neurons exhibit properties of GluA2-lacking AMPA receptors

To identify synaptic changes responsible for the GluAl overexpression-mediated acceleration of CPP acquisition, we obtained CeA slices from rats after singleside CeA injection of AAV vectors and performed whole-cell voltage-clamp recordings in infected, GFP-labeled neurons in $\mathrm{CeA}$ of the injected side and control CeA neurons in the other uninjected side (Fig. 6A). In those GFPpositive, likely AAV-GluA1-transfected neurons, we found a significant increase in the ratio of AMPA EPSC over NMDA EPSC when compared to the ratio in control neurons (one-way ANOVA: $F_{(2,33)}=4.909$, $p<0.05$; post hoc Tukey's test: $p<0.05$ for both comparisons, Fig. $6 B, C$ ). Compared to controls, no significant change in the ratio was observed in AAV-GluA1-shRNAinfected neurons. Next, we analyzed the rectification property of AMPA EPSCs, a unique feature of GluA2-lacking, $\mathrm{Ca}^{2+}$ permeable AMPA receptors (Isaac et al., 2007). The current-voltage relationship of AMPA EPSCs in GluA1-overexpressing cells showed significant inward rectification (one-way ANOVA: $F_{(2,34)}=5.629, p<$ 0.01 ; post hoc Tukey's test: control vs. GluA1-GFP, $p<0.05$; GluA1-GFP vs. GluA1-shRNA, $p<0.05$, Fig. $6 D$ ). Furthermore, blocking GluA2-lacking AMPA receptors by bath application of 1-naphthyl acetyl spermine (NASPM, $100 \mu \mathrm{M}$ ) significantly decreased the EPSC amplitude only in GluA1-overexpressing cells (one-way ANOVA: $F_{(2,22)}=8.365, p<0.01$; post hoc Tukey's test: $p<0.01$ for both comparisons, Fig. 6E). In comparison with controls, no statistically significant change was found either in the rectification of AMPA EPSCs or in the NASPM effect in AAV-GluA1shRNA-infected neurons, perhaps reflecting the viral downregulation of both GluA1 and GluA2 shown in Figure $5 A$. In addition, the paired-pulse ratio (PPR), a commonly used synaptic measure for changes in the probability of presynaptic transmitter release (Zucker and Regehr, 2002), remained unaltered across the three groups of neurons (one-way ANOVA: $F_{(2,31)}=0.1652$, $p=0.8485$, Fig. $6 F)$, suggesting that the change in GluAl subunit expression primarily affected the properties of postsynaptic AMPA receptors rather than presynaptic glutamate release in these CeA neurons.

GluA2-lacking AMPA receptor is important for morphineinduced CPP

We then determined whether CeA GluA2-lacking AMPA receptors were critical for the acquired CPP behavior induced by mor- 
A
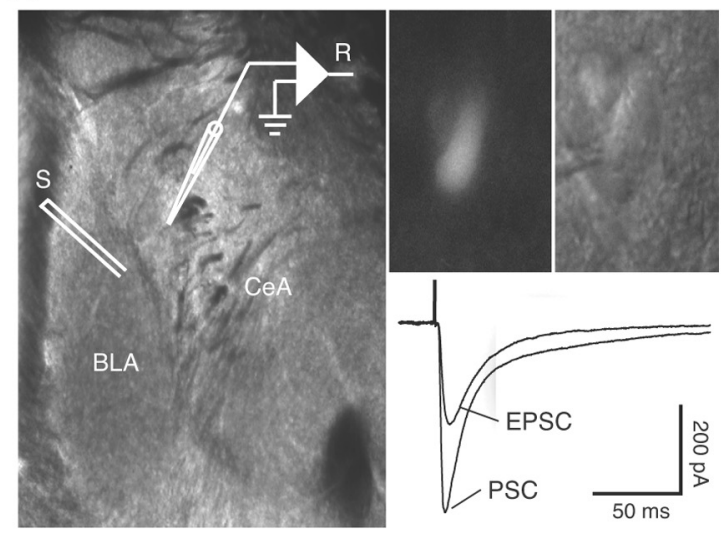

$\mathrm{D}$
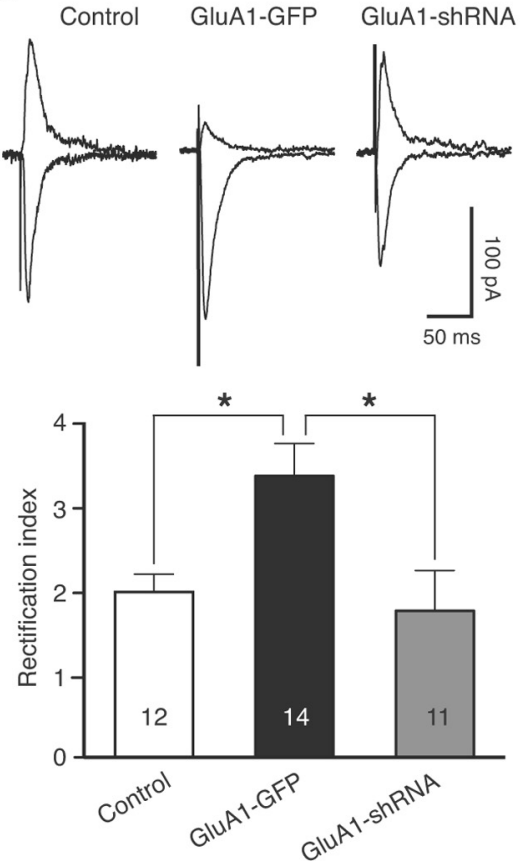

E Control
B

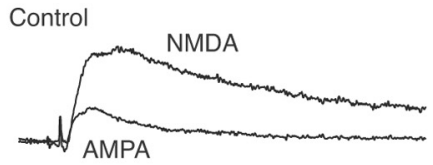

GluA1-GFP

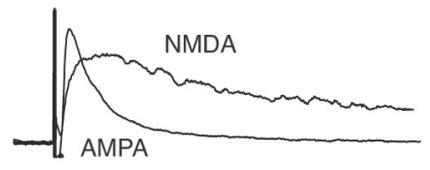

GluA1-shRNA

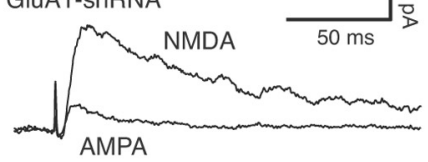

GluA1-GFP GluA1-shRNA

$\mathrm{F}$
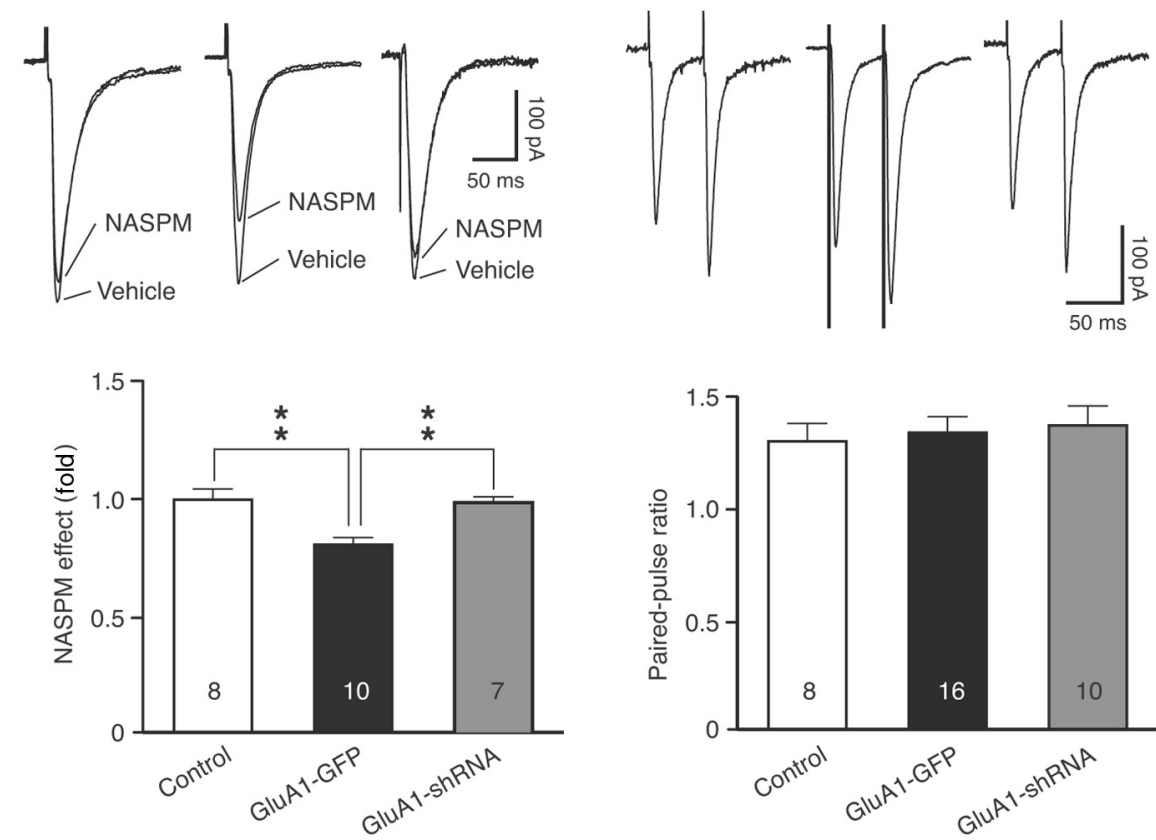

C

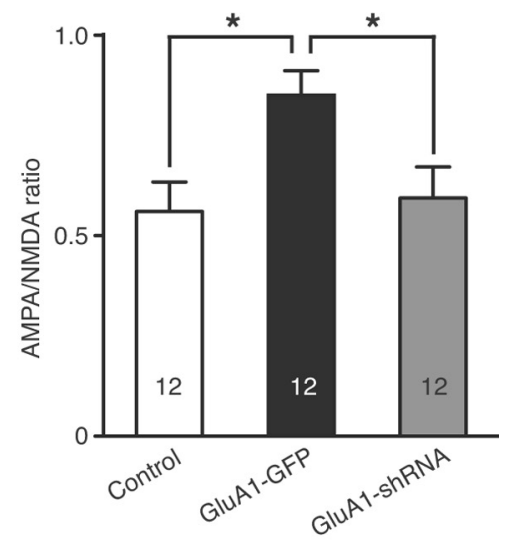

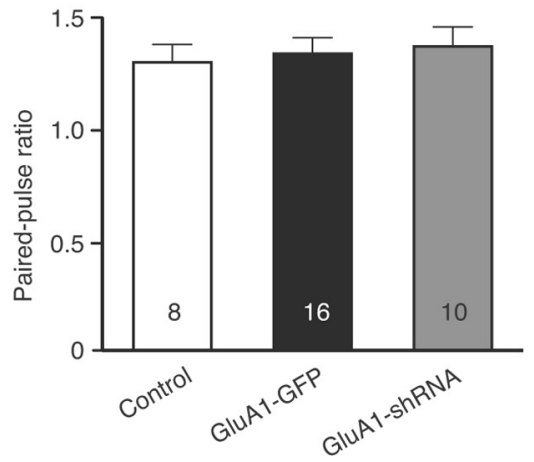

Figure 6. GluA1 overexpression increases synaptic properties of GluA2-lacking AMPA receptors in CeA neurons. $A$, Illustration of stimulation (S) placement in BLA, and recording (R) of a viral vector-transfected neuron and EPSC in a CeA slice. A transfected cell was identified by the GFP fluorescence (top middle) and recorded in whole-cell configuration (top right) with a typical postsynaptic current (PSC) and excitatory postsynaptic current (EPSC) in the presence of picrotoxin (50 $\mu \mathrm{M})$ (bottom right). B, Representative AMPA EPSCs and NMDA EPSCs in a control cell and in transfected cells from animals after single-side CeA injection of the mixture (GluA1-GFP) of AAV-GluA1 and AAV-GFP vectors (3:1) or AAV-GluA1-shRNA-GFP vector. C, Summarized results of the AMPA/NMDA EPSC ratio in the three indicated cell groups. Numbers in columns are cell numbers in each group. $D$, EPSCs at holding potentials of $+40 \mathrm{mV}$ and $-70 \mathrm{mV}$ in the presence of the NMDA receptor antagonist D-AP5 (50 $\mu \mathrm{M}$ ) (top) and the calculated rectification index of EPSCS (bottom) in the three cell groups. $E$, EPSCs (top) and summarized results (bottom) before and during application of the GluA2-lacking AMPA receptor antagonist NASPM (100 $\mu \mathrm{M}$ ) in the indicated cell groups. F, Evoked EPSC pairs (50 ms apart, top) and summarized data of paired-pulse ratios (bottom) in the three cell groups. ${ }^{*} p<0.05,{ }^{* *} p<0.01$.

phine. We found that $\mathrm{CPP}$ in rats conditioned with morphine (10 $\mathrm{mg} / \mathrm{kg}, 4$ sessions) was significantly attenuated by bilateral intraCeA infusion of NASPM ( $40 \mu \mathrm{g}$, each side) (morphine group: $t_{(7)}$ $=6.517, p<0.01$; morphine plus NASPM group: $t_{(7)}=4.804$, $p<0.01$; two-way ANOVA: $F_{(1,14)}=9.39, p<0.01$, Fig. $\left.7 A\right)$. CeA infusion of NASPM alone did not change preference behavior in naive rats $\left(t_{(5)}=0.8285, p=0.4451\right)$. To further determine the behavioral significance of CeA AMPA receptors, we substituted morphine with AMPA to directly activate the AMPA receptors in the conditioning procedures. Rats similarly conditioned in 4 sessions with AMPA (100 ng in $0.5 \mu \mathrm{l}$, each side) bilaterally infused into CeA displayed significant CPP (AMPA group: $t_{(7)}=7.069$, $p<0.01$; AMPA plus NASMP group: $t_{(7)}=4.990, p<0.01$ ), and similar to morphine-induced CPP, the AMPA-induced CPP also was largely inhibited by CeA pre-infusion of NASPM ( $40 \mu \mathrm{g}$, each side, 30 min before AMPA infusion) (two-way ANOVA: $F_{(1,14)}=$ $9.78, p<0.01$, Fig. $7 B$ ). Thus, it appears that activation of CeA AMPA receptors is rewarding, sufficient to induce $\mathrm{CPP}$ behavior, and the GluA2-lacking AMPA receptor is important for this rewarding effect, consistent with its role in facilitating the acquisition of reward-related behavior.

\section{GluA2 knockdown facilitates associative learning of morphine reward}

To determine the role of CeA GluA2 subunits in the behavior of opioid reward, we constructed AAV-GluA2-shRNA vectors and 

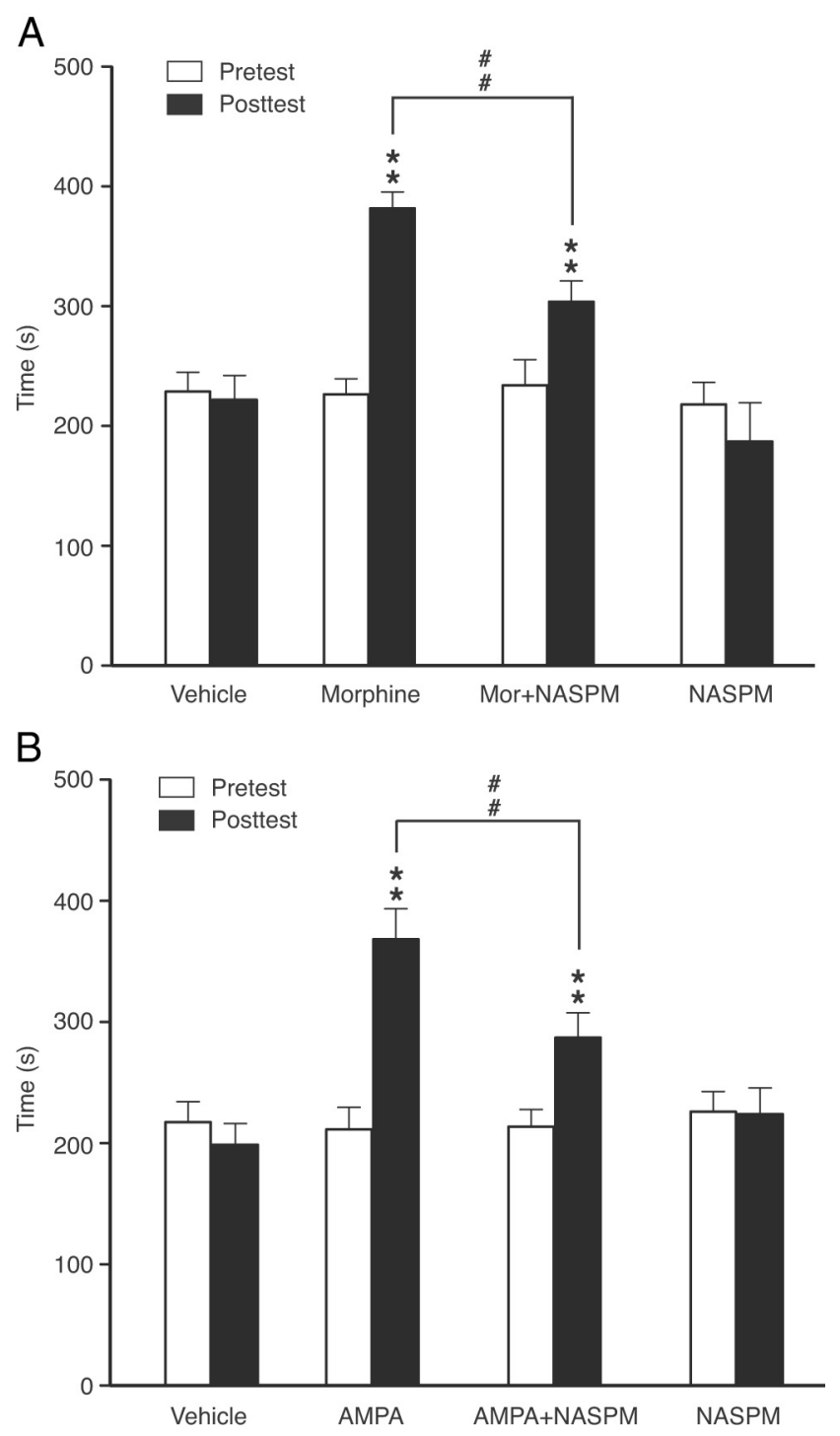

Figure 7. GluA2-lacking AMPA receptors in CeA are involved in acquired behavior of opioid reward. $A$, Behaviors of CPP in rats conditioned in 4 sessions with PBS as vehicle, morphine (10 $\mathrm{mg} / \mathrm{kg}$ ) without or with bilateral pre-CeA infusion ( $15 \mathrm{~min}$ before) of NASPM ( $40 \mu \mathrm{g}$, each side), or vehicle with CeA pre-infusion of NASPM. ${ }^{* *} p<0.01$ (compared to the pretest); ${ }^{\# \#} p<0.01$ (compared between the indicated two groups) ( $n=8$ rats in each group). $\boldsymbol{B}$, (PP behaviors in similar groups of rats with morphine substituted by AMPA ( $100 \mathrm{ng}$, each side) infused similarly into CeA in the conditioning procedure. ${ }^{* *} p<0.01$ (compared to the pretest); ${ }^{\# \#} p<0.01$ (compared between the indicated two groups); $n=8$ rats in each group.

infused the virus into CeA to knockdown GluA2 expression. Bilateral infusion of AAV-GluA2-shRNA vectors significantly decreased the GluA2 level by 68 and $63 \%$ in CeA synaptosomal $\left.t_{(6)}=6.066, p<0.01\right)$ and cytoplasmic $\left(t_{(6)}=3.164, p<0.05\right)$ protein preparations, respectively, when compared to those from animals treated with AAV-scrambled shRNA (Fig. 8A). In contrast, cytoplasmic GluA1 level was not altered by the AAV-GluA2-shRNA vector, while synaptosomal GluA1 was moderately reduced $\left(t_{(6)}=2.762, p<0.05\right)$, a finding consistent with a previous report (Mead and Stephens, 2003b). Behaviorally, control rats treated with CeA infusion of scrambled GluA2shRNA displayed CPP after one session and the following 4 sessions of conditioning with morphine ( $3 \mathrm{mg} / \mathrm{kg}$, s.c.); however, rats treated similarly with AAV-GluA2-shRNA showed consistently stronger $\mathrm{CPP}$ than control rats (two-way ANOVA: $F_{(1,16)}=$ $6.88, p=0.0185$, Fig. $8 B$ ), an effect similar to that of GluA1 overexpression (Fig. 4C). But unlike the learning-facilitating effect of GluA1 overexpression on both CPP acquisition and CPP extinction, GluA2 knockdown failed to accelerate CPP extinction (Fig. $8 B$ ), with CPP in both groups declined at a similar rate during extinction training, as in the rat groups treated with two different morphine doses (Fig. 4D).

\section{CeA GluA1 is not involved in learning of novel objects}

Finally, we conducted the novel object recognition test to determine whether CeA GluA1 was involved in the learning process of novel objects and related recognition memory. Behaviors of object exploration were compared among three groups of rats with CeA infusion of AAV-GFP for control, AAV-GluA1 for GluA1 overexpression, or AAV-GluA1-shRNA for GluA1 knockdown. Rats in all three groups preferred exploring the novel object to the familiar object (AAV-GFP: $t_{(10)}=5.316, p<0.01$; AAV-GluA1: $t_{(10)}=4.576, p<0.01$; AAV-GluA1-shRNA: $t_{(10)}=6.158, p<$ 0.01 , Fig. $8 C$ ). The exploration times in the AAV-GluA1-shRNA group slightly decreased when compared to the other two groups, but the difference was not statistically significant (one-way ANOVA: $F_{(2,15)}=2.058, p=0.1622$, Fig. $\left.8 C\right)$. When the novel preference was compared, there was no significant difference among the three groups (one-way ANOVA: $F_{(2,15)}=0.2349, p=$ 0.7935 , Fig. $8 D$ ). This suggests that upregulation or downregulation of CeA GluA1 does not have a generalized effect on object learning and recognition memory.

\section{Discussion}

In the present study, we have provided biochemical, electrophysiological and behavioral data to suggest that increased expression and function of GluA2-lacking AMPA receptors in CeA likely facilitates the learning and consolidation of environmental context-reward association, an important process in the development of drug-seeking behavior as well as in relapse of such behaviors in opioid addiction.

The amygdala is known for regulating and coordinating emotional behaviors in response to various persistent environmental stimuli and emotional events generally promote learning and memory via amygdala functions (Baxter and Murray, 2002; Everitt et al., 2003; Maren, 2005; Knapska et al., 2007; Murray, 2007; Roozendaal et al., 2009; Tye et al., 2011). The vast majority of previous studies have been focused on amygdala regulation of negative emotional behaviors represented by fear responses (Kalin et al., 2004; Maren, 2005; Knapska et al., 2007; Ehrlich et al., 2009; Tye et al., 2011). Recent evidence increasingly suggests that the amygdala including CeA is part of the brain's reward circuitry and is important also in regulation of positive emotions represented by reward-related responses (Baxter and Murray, 2002; See et al., 2003). The role of amygdala including CeA in behaviors of opioid reward has been shown in a number of studies and the receptor and signaling systems involved include NMDA receptors, cannabinoid CB1 receptors, dopamine receptors, neurokinin-1 receptors, ERK and PKMzeta (Gadd et al., 2003; Zarrindast et al., 2003; Rezayof et al., 2007; Li et al., 2008; Bishop et al., 2011; He et al., 2011; Li et al., 2011; Rezayof et al., 2011). However, local injection of morphine into the lateral nucleus of the amygdala did not induce CPP (Olmstead and Franklin, 1997).

Our data from the current study indicate that reward conditioning with morphine increases expression and synaptic strength of GluA2-lacking AMPA receptors in CeA neurons, which promotes the associative learning of opioid reward in positive emotional behaviors. This is consistent with a recent study showing that in vivo optogenetic stimulation of the glutamatergic 
pathway from BLA to nucleus accumbens (NAc) promotes motivated response of reward-seeking behaviors (Stuber et al., 2011). Given the extensive glutamatergic inputs from BLA neurons onto CeA neurons (Pitkänen et al., 1997; Swanson and Petrovich, 1998), the adaptive increase in GluA1 expression and in the synaptic strength of GluA2-lacking AMPA receptors in CeA could be driven by persistent stimulating activity of the BLA-CeA glutamatergic pathway and operates as part of the mechanisms underlying motivated reward-seeking behaviors through facilitated reward learning.

This CeA GluA1 function of learning facilitation is in agreement with a general rewarding effect of GluAl subunits and AMPA receptors found in other rewardrelated brain areas. For instance, repeated exposure to morphine or cocaine increases GluAl expression in VTA and hippocampal neurons, and GluA1 upregulation in VTA enhances the rewarding effect of morphine or motivation for cocaine self-administration (Fitzgerald et al., 1996; Carlezon et al., 1997; Billa et al., 2010; Choi et al., 2011). Activation of CeA AMPA receptors by local infusion of AMPA increases extracellular dopamine level in several brain regions including prefrontal cortex and NAc (Stalnaker and Berridge, 2003). Our data suggest that CeA GluA1 is important in the learning and acquisition of reward-seeking behavior, as evidenced by increased expression of synaptic GluA1 during the proposed period of reward learning and consolidation. It is interesting to note that the synaptic GluA1 protein returned to pre-morphine level after the acquisition and establishment of CPP behavior while synaptic GluA2lacking AMPA receptors were still required partially for the established CPP behavior. This is consistent with previous reports of no change in GluA1 expression in VTA and NAc of rats with established, cocaine-induced CPP (Carlezon and Nestler, 2002; Plant et al., 2006; Hu et al., 2007; Bachtell and Self, 2008; Matsuo et al., 2008; Edwards et al., 2009; Choi et al., 2011), and might reflect an intense increase in synaptic GluA1 through new GluA1 synthesis and synaptic insertion required for synaptic facilitation only during associative learning of reward, with synaptic GluA1 returning to a more moderate and sustainable level after acquisition. This notion of CeA GluA1 more important for associative learning and acquisition of reward is in line with the general concept that CeA primarily is not involved in storage of emotional memory (Maren, 2005; Knapska et al., 2007; Vlachos et al., 2009). As supported by our electrophysiological data, upregulation of GluA1 expression may change the subunit composition of membrane AMPA receptors and switch GluA2containing AMPA receptors to GluA2-lacking AMPA receptors with enhanced synaptic strength in response to glutamatergic input activities (Bowers et al., 2010).

Extinction of addictive behaviors in animals involves a type of learning that is thought to form a new memory, which suppresses behavioral response to a previously learned stimulus (Bouton,
2002; See et al., 2003). Since no drug was involved in extinction training, it permitted the current study to determine CeA GluA1 role in an alternative form of associative learning without the influence of the pharmacological effect of morphine. Our data of CPP extinction support the effect of CeA GluA1-mediated learning facilitation rather than a sensitized pharmacological effect of morphine per se. This role of CeA GluA1 is in line with previous studies demonstrating a generally consistent extinctionpromoting effect of GluA1 subunits in cocaine-seeking behavior in other brain regions of reward (Sutton et al., 2003; Engblom et al., 2008). Of note is the report that deletion of AMPA receptor binding protein Narp, which is highly expressed in the amygdala, blocks extinction of morphine-induced CPP (Crombag et al., 2009). Interestingly, mice lacking GluA1 can learn to associate a light/tone stimulus with food reward, but show inhibited ability to associate the cue with a new behavior of reward (Mead and Stephens, 2003a). In addition, our results of the novel object recognition test indicate that $\mathrm{CeA}$ GluA1, while important in associative learning of opioid reward, may not be involved in learning of novel objects and related recognition memory.

Our data showed that shRNA downregulation of GluA1 or GluA2 also significantly decreased GluA2 or GluA1, respectively, in CeA synaptosomal preparations. This is unlikely caused by the off-target effect of the shRNA sequence because the shRNA sequence does not have potential target sequences of the other subunit in rat mRNA by blast analysis. In fact, this associated change in the expression of GluA1 and GluA2 has been reported 
in previous studies, which showed that deletion of either of GluA1 or GluA2 would disrupt and decrease the expression of the other subunit in BLA and hippocampus (Zamanillo et al., 1999; Mead and Stephens, 2003a; Mead and Stephens, 2003b). However, overexpression of GluA1 did not increase the GluA2 level in our study, nor was it reported in previous studies (Carlezon et al., 1997; Shi et al., 1999; Mack et al., 2001; Sutton et al., 2003; Rumpel et al., 2005; Schmitt et al., 2005; Matsuo et al., 2008). Thus, it appears that, whereas GluA2-lacking AMPA receptors could be upregulated independently of GluA2 subunits in the synapse, a certain level of GluA1 and GluA2 subunits may be required to maintain the synaptic function of GluA1/2 AMPA receptors. Although the molecular mechanism for interactive assembly and trafficking of GluA1 and GluA2 heterotetramers is still unclear, it is consistent with the notion that, of GluA1 and GluA2 subunits, lack of one type inhibits membrane insertion of the other and their co-assembly on synapses (Zamanillo et al., 1999). The shared facilitating effect on CPP acquisition but differential effects on CPP extinction by GluA1 overexpression and GluA2 knockdown may indicate that GluAl is more actively and predominantly involved in the associative learning than GluA2. As knockdown of one subunit type also decreases the other, this off-target effect should be cautiously considered in data interpretation of GluA1 and GluA2 roles.

Given the direct glutamatergic projections from BLA to CeA and predominant glutamatergic neurons in BLA (Sah et al., 2003), it would be intriguing to investigate whether GluAl in BLA neurons has a similar or differential role in associative learning for behaviors of opioid reward. Due to potential spillover of the injected viral vector into BLA, such a role of BLA GluA1 in the behavioral effects we observed cannot be excluded.

In summary, the present study suggests that increased expression of GluA1 subunits, and consequently upregulation of GluA2-lacking AMPA receptors, in CeA neurons may facilitate learning and consolidation of context-drug reward association, resulting in accelerated acquisition of behavior of opioid reward and its inhibition by new conditioning stimuli. In a clinical perspective, this may imply an important role of CeA GluA1 subunits in promoting early development of drug-seeking behaviors leading to drug addiction and in alleviating drug-seeking behaviors after drug withdrawal.

\section{References}

Bachtell RK, Self DW (2008) Renewed cocaine exposure produces transient alterations in nucleus accumbens AMPA receptor-mediated behavior. J Neurosci 28:12808-12814. CrossRef Medline

Bachtell RK, Choi KH, Simmons DL, Falcon E, Monteggia LM, Neve RL, Self DW (2008) Role of GluR1 expression in nucleus accumbens neurons in cocaine sensitization and cocaine-seeking behavior. Eur J Neurosci 27: 2229-2240. CrossRef Medline

Balland B, Lachamp P, Strube C, Kessler JP, Tell F (2006) Glutamatergic synapses in the rat nucleus tractus solitarii develop by direct insertion of calcium-impermeable AMPA receptors and without activation of NMDA receptors. J Physiol 574:245-261. CrossRef Medline

Baxter MG, Murray EA (2002) The amygdala and reward. Nat Rev Neurosci 3:563-573. CrossRef Medline

Bevins RA, Besheer J (2006) Object recognition in rats and mice: a one-trial non-matching-to-sample learning task to study 'recognition memory'. Nat Protoc 1:1306-1311. CrossRef Medline

Bie B, Zhu W, Pan ZZ (2009) Rewarding morphine-induced synaptic function of delta-opioid receptors on central glutamate synapses. J Pharmacol Exp Ther 329:290-296. CrossRef Medline

Billa SK, Liu J, Bjorklund NL, Sinha N, Fu Y, Shinnick-Gallagher P, Morón JA (2010) Increased insertion of glutamate receptor 2-lacking alpha-amino3-hydroxy-5-methyl-4-isoxazole propionic acid (AMPA) receptors at hippocampal synapses upon repeated morphine administration. Mol Pharmacol 77:874-883. CrossRef Medline

Bishop SF, Lauzon NM, Bechard M, Gholizadeh S, Laviolette SR (2011) NMDA receptor hypofunction in the prelimbic cortex increases sensitivity to the rewarding properties of opiates via dopaminergic and amygdalar substrates. Cerebr Cort 21:68-80. CrossRef Medline

Bouton ME (2002) Context, ambiguity, and unlearning: sources of relapse after behavioral extinction. Biol Psychiatry 52:976-986. CrossRef Medline

Bowers MS, Chen BT, Bonci A (2010) AMPA receptor synaptic plasticity induced by psychostimulants: the past, present, and therapeutic future. Neuron 67:11-24. CrossRef Medline

Carlezon WA Jr, Boundy VA, Haile CN, Lane SB, Kalb RG, Neve RL, Nestler EJ (1997) Sensitization to morphine induced by viral-mediated gene transfer. Science 277:812-814. CrossRef Medline

Carlezon WA Jr, Nestler EJ (2002) Elevated levels of GluR1 in the midbrain: a trigger for sensitization to drugs of abuse? Trends Neurosci 25:610-615. CrossRef Medline

Choi KH, Edwards S, Graham DL, Larson EB, Whisler KN, Simmons D, Friedman AK, Walsh JJ, Rahman Z, Monteggia LM, Eisch AJ, Neve RL, Nestler EJ, Han MH, Self DW (2011) Reinforcement-related regulation of AMPA glutamate receptor subunits in the ventral tegmental area enhances motivation for cocaine. J Neurosci 31:7927-7937. CrossRef Medline

Conrad KL, Tseng KY, Uejima JL, Reimers JM, Heng LJ, Shaham Y, Marinelli M, Wolf ME (2008) Formation of accumbens GluR2-lacking AMPA receptors mediates incubation of cocaine craving. Nature 454:118-121. CrossRef Medline

Crombag HS, Dickson M, Dinenna M, Johnson AW, Perin MS, Holland PC, Baraban JM, Reti IM (2009) Narp deletion blocks extinction of morphine place preference conditioning. Neuropsychopharmacology 34: 857-866. CrossRef Medline

Edwards S, Graham DL, Whisler KN, Self DW (2009) Phosphorylation of GluR1, ERK, and CREB during spontaneous withdrawal from chronic heroin self-administration. Synapse 63:224-235. CrossRef Medline

Ehrlich I, Humeau Y, Grenier F, Ciocchi S, Herry C, Lüthi A (2009) Amygdala inhibitory circuits and the control of fear memory. Neuron 62:757-771. CrossRef Medline

Engblom D, Bilbao A, Sanchis-Segura C, Dahan L, Perreau-Lenz S, Balland B, Parkitna JR, Luján R, Halbout B, Mameli M, Parlato R, Sprengel R, Lüscher C, Schütz G, Spanagel R (2008) Glutamate receptors on dopamine neurons control the persistence of cocaine seeking. Neuron 59:497508. CrossRef Medline

Everitt BJ, Cardinal RN, Parkinson JA, Robbins TW (2003) Appetitive behavior: impact of amygdala-dependent mechanisms of emotional learning. Ann N Y Acad Sci 985:233-250. CrossRef Medline

Fitzgerald LW, Ortiz J, Hamedani AG, Nestler EJ (1996) Drugs of abuse and stress increase the expression of GluR1 and NMDAR1 glutamate receptor subunits in the rat ventral tegmental area: common adaptations among cross-sensitizing agents. J Neurosci 16:274-282. Medline

Gadd CA, Murtra P, De Felipe C, Hunt SP (2003) Neurokinin-1 receptorexpressing neurons in the amygdala modulate morphine reward and anxiety behaviors in the mouse. J Neurosci 23:8271-8280. Medline

Gao GP, Alvira MR, Wang L, Calcedo R, Johnston J, Wilson JM (2002) Novel adeno-associated viruses from rhesus monkeys as vectors for human gene therapy. Proc Natl Acad Sci U S A 99:11854-11859. CrossRef Medline

Hayashi Y, Shi SH, Esteban JA, Piccini A, Poncer JC, Malinow R (2000) Driving AMPA receptors into synapses by LTP and CaMKII: requirement for GluR1 and PDZ domain interaction. Science 287:2262-2267. CrossRef Medline

He YY, Xue YX, Wang JS, Fang Q, Liu JF, Xue LF, Lu L (2011) PKMzeta maintains drug reward and aversion memory in the basolateral amygdala and extinction memory in the infralimbic cortex. Neuropsychopharmacology 36:1972-1981. CrossRef Medline

Hu H, Real E, Takamiya K, Kang MG, Ledoux J, Huganir RL, Malinow R (2007) Emotion enhances learning via norepinephrine regulation of AMPA-receptor trafficking. Cell 131:160-173. CrossRef Medline

Hyman SE, Malenka RC, Nestler EJ (2006) Neural mechanisms of addiction: the role of reward-related learning and memory. Annu Rev Neurosci 29:565-598. CrossRef Medline

Ikemoto S, Witkin BM, Zangen A, Wise RA (2004) Rewarding effects of 
AMPA administration into the supramammillary or posterior hypothalamic nuclei but not the ventral tegmental area. J Neurosci 24:5758-5765. CrossRef Medline

Isaac JT, Ashby MC, McBain CJ (2007) The role of the GluR2 subunit in AMPA receptor function and synaptic plasticity. Neuron 54:859-871. CrossRef Medline

Kalin NH, Shelton SE, Davidson RJ (2004) The role of the central nucleus of the amygdala in mediating fear and anxiety in the primate. J Neurosci 24:5506-5515. CrossRef Medline

Kauer JA, Malenka RC (2007) Synaptic plasticity and addiction. Nat Rev Neurosci 8:844-858. CrossRef Medline

Knapska E, Radwanska K, Werka T, Kaczmarek L (2007) Functional internal complexity of amygdala: focus on gene activity mapping after behavioral training and drugs of abuse. Physiol Rev 87:1113-1173. CrossRef Medline

Koob GF, Volkow ND (2010) Neurocircuitry of addiction. Neuropsychopharmacology 35:217-238. CrossRef Medline

Li F, Wang XS, Dai RP, Zhang JY, Zhou XF, Hao W, Li CQ (2011) The activation of NMDA receptor-ERK pathway in the central amygdala is required for the expression of morphine-conditioned place preference in the rat. Neurotox Res 20:362-371. CrossRef Medline

Li YQ, Li FQ, Wang XY, Wu P, Zhao M, Xu CM, Shaham Y, Lu L (2008) Central amygdala extracellular signal-regulated kinase signaling pathway is critical to incubation of opiate craving. J Neurosci 28:13248-13257. CrossRef Medline

Mack V, Burnashev N, Kaiser KM, Rozov A, Jensen V, Hvalby O, Seeburg PH, Sakmann B, Sprengel R (2001) Conditional restoration of hippocampal synaptic potentiation in Glur-A-deficient mice. Science 292:2501-2504. CrossRef Medline

Maren S (2005) Synaptic mechanisms of associative memory in the amygdala. Neuron 47:783-786. CrossRef Medline

Matsuo N, Reijmers L, Mayford M (2008) Spine-type-specific recruitment of newly synthesized AMPA receptors with learning. Science 319:1104-1107. CrossRef Medline

McGaugh JL (2000) Memory-a century of consolidation. Science 287: 248-251. CrossRef Medline

Mead AN, Stephens DN (2003a) Selective disruption of stimulus-reward learning in glutamate receptor grial knock-out mice. J Neurosci 23:10411048. Medline

Mead AN, Stephens DN (2003b) Involvement of AMPA receptor GluR2 subunits in stimulus-reward learning: evidence from glutamate receptor gria2 knock-out mice. J Neurosci 23:9500-9507. Medline

Murray EA (2007) The amygdala, reward and emotion. Trends Cogn Sci 11:489-497. CrossRef Medline

Olmstead MC, Franklin KB (1997) The development of a conditioned place preference to morphine: effects of microinjections into various CNS sites. Behav Neurosci 111:1324-1334. CrossRef Medline

Paxinos G, Watson C (1986) The rat brain in stereotaxic coordinates, 2nd Edition. Sydney: Academic press.

Pitkänen A, Savander V, LeDoux JE (1997) Organization of intra-amygdaloid circuitries in the rat: an emerging framework for understanding functions of the amygdala. Trends Neurosci 20:517-523. CrossRef Medline

Plant K, Pelkey KA, Bortolotto ZA, Morita D, Terashima A, McBain CJ, Collingridge GL, Isaac JT (2006) Transient incorporation of native GluR2-lacking AMPA receptors during hippocampal long-term potentiation. Nat Neurosci 9:602-604. CrossRef Medline

Rezayof A, Golhasani-Keshtan F, Haeri-Rohani A, Zarrindast MR (2007) Morphine-induced place preference: involvement of the central amygdala NMDA receptors. Br Res 1133:34-41. CrossRef Medline

Rezayof A, Sardari M, Zarrindast MR, Nayer-Nouri T (2011) Functional interaction between morphine and central amygdala cannabinoid CB1 receptors in the acquisition and expression of conditioned place preference. Behav Br Res 220:1-8. CrossRef Medline

Robbins TW, Ersche KD, Everitt BJ (2008) Drug addiction and the memory systems of the brain. Ann N Y Acad Sci 1141:1-21. CrossRef Medline

Roozendaal B, McEwen BS, Chattarji S (2009) Stress, memory and the amygdala. Nat Rev Neurosci 10:423-433. CrossRef Medline
Rumpel S, LeDoux J, Zador A, Malinow R (2005) Postsynaptic receptor trafficking underlying a form of associative learning. Science 308:83-88. CrossRef Medline

Sah P, Faber ES, Lopez De Armentia M, Power J (2003) The amygdaloid complex: anatomy and physiology. Physiol Rev 83:803-834. CrossRef Medline

Schmitt WB, Sprengel R, Mack V, Draft RW, Seeburg PH, Deacon RM, Rawlins JN, Bannerman DM (2005) Restoration of spatial working memory by genetic rescue of GluR-A-deficient mice. Nat Neurosci 8:270-272. CrossRef Medline

See RE, Fuchs RA, Ledford CC, McLaughlin J (2003) Drug addiction, relapse, and the amygdala. Ann N Y Acad Sci 985:294-307. CrossRef Medline

Shi SH, Hayashi Y, Petralia RS, Zaman SH, Wenthold RJ, Svoboda K, Malinow R (1999) Rapid spine delivery and redistribution of AMPA receptors after synaptic NMDA receptor activation. Science 284:1811-1816. CrossRef Medline

Sommer B, Keinänen K, Verdoorn TA, Wisden W, Burnashev N, Herb A, Köhler M, Takagi T, Sakmann B, Seeburg PH (1990) Flip and flop: a cell-specific functional switch in glutamate-operated channels of the CNS. Science 249:1580-1585. CrossRef Medline

Stalnaker TA, Berridge CW (2003) AMPA receptor stimulation within the central nucleus of the amygdala elicits a differential activation of central dopaminergic systems. Neuropsychopharmacology 28:1923-1934. CrossRef Medline

Stuber GD, Sparta DR, Stamatakis AM, van Leeuwen WA, Hardjoprajitno JE, Cho S, Tye KM, Kempadoo KA, Zhang F, Deisseroth K, Bonci A (2011) Excitatory transmission from the amygdala to nucleus accumbens facilitates reward seeking. Nature 475:377-380. CrossRef Medline

Sutton MA, Schmidt EF, Choi KH, Schad CA, Whisler K, Simmons D, Karanian DA, Monteggia LM, Neve RL, Self DW (2003) Extinction-induced upregulation in AMPA receptors reduces cocaine-seeking behaviour. $\mathrm{Na}$ ture 421:70-75. CrossRef Medline

Swanson LW, Petrovich GD (1998) What is the amygdala? Trends Neurosci 21:323-331. CrossRef Medline

Tye KM, Prakash R, Kim SY, Fenno LE, Grosenick L, Zarabi H, Thompson KR, Gradinaru V, Ramakrishnan C, Deisseroth K (2011) Amygdala circuitry mediating reversible and bidirectional control of anxiety. Nature 471:358-362. CrossRef Medline

Tzschentke TM (2007) Measuring reward with the conditioned place preference (CPP) paradigm: update of the last decade. Addict Biol 12:227-462. CrossRef Medline

Vlachos A, Korkotian E, Schonfeld E, Copanaki E, Deller T, Segal M (2009) Synaptopodin regulates plasticity of dendritic spines in hippocampal neurons. J Neurosci 29:1017-1033. CrossRef Medline

Zamanillo D, Sprengel R, Hvalby O, Jensen V, Burnashev N, Rozov A, Kaiser KM, Köster HJ, Borchardt T, Worley P, Lübke J, Frotscher M, Kelly PH, Sommer B, Andersen P, Seeburg PH, Sakmann B (1999) Importance of AMPA receptors for hippocampal synaptic plasticity but not for spatial learning. Science 284:1805-1811. CrossRef Medline

Zarrindast MR, Rezayof A, Sahraei H, Haeri-Rohani A, Rassouli Y (2003) Involvement of dopamine D1 receptors of the central amygdala on the acquisition and expression of morphine-induced place preference in rat. Br Res 965:212-221. CrossRef Medline

Zhang Z, Pan ZZ (2010) Synaptic mechanism for functional synergism between delta- and mu-opioid receptors. J Neurosci 30:4735-4745. CrossRef Medline

Zhang Z, Cai YQ, Zou F, Bie B, Pan ZZ (2011) Epigenetic suppression of GAD65 expression mediates persistent pain. Nat Med 17:1448-1455. CrossRef Medline

Zhu W, Bie B, Pan ZZ (2007) Involvement of non-NMDA glutamate receptors in central amygdala in synaptic actions of ethanol and ethanolinduced reward behavior. J Neurosci 27:289-298. CrossRef Medline

Zucker RS, Regehr WG (2002) Short-term synaptic plasticity. Annu Rev Physiol 64:355-405. CrossRef Medline 